\title{
The Regulatory Gift: Politics, Regulation and Governance
}

\author{
Jude Browne
}

\section{University of Cambridge}

\begin{abstract}
This article introduces the 'regulatory gift' as a conceptual framework for understanding a particular form of government-led deregulation that is presented as central to the public interest. Contra to theories of regulatory capture, government corruption, 'insider' personal interest or profit-seeking theories of regulation, the regulatory gift describes reform which is overtly designed by Government to reduce or reorient regulators' functions to the advantage of the regulated and in line with market objectives on a potentially macro (rather than industry-specific) scale. As a conceptual framework, the regulatory gift is intended to be applicable across regulated sectors of democratic states and in this article the empirical sections evidence the practice of regulatory gifting in contemporary UK politics. Specifically, this article analyses the UK Public Bodies Act (2011), affecting some 900 regulatory public bodies and its correlative legislation, the Regulator's Code (2014), the Deregulation Act (2015) and the Enterprise Bill (2016). The article concludes that whilst the regulatory gift may, in some cases, be aligned with the public interest - delivering on cost reduction, enhancing efficiency and stimulating innovation - this will not always be the case. As the case study of the regulatory body, the UK Human Fertilisation and Embryology Authority (HFEA) demonstrates, despite the explicit claims made by legislators, the regulatory gift has the potential to significantly undermine the public interest.
\end{abstract}

As one of the state's core functions, regulation is intensely political. The specific form that regulation takes and the way that it is administered are fundamentally important to the relationships between the state, industry and the public. Much of regulation scholarship has focused on the shortcomings of regulators and how best to counter their failures. Regulators have been shown to create obstacles to market innovation, be inefficient and wasteful of public 
funds as well as effecting a 'democratic deficit' in virtue of centralising regulatory power in the hands of unelected decision-makers with too little engagement with the elected executive (LeviFaur, 2011). Further still, some regulators are seen as being particularly vulnerable to 'regulatory capture" whereby those "tasked with protecting the public interest come to identify with the regulated industry and protect its interests against that of the public" (Becker 2011). Responses to these sorts of regulation failure include greater constraints on regulators based on more intense cost-benefit analyses (Sunstein 2013), the reduction of regulation to a lighter-touch 'cooperative' regulation focused on voluntary targets and best practices (Baldwin 2008), or more radically - deregulation (Rhan 2011).

Whilst there are strong arguments in favour of these views in particular contexts, in this article I nevertheless want to take a different sort of perspective on the challenges that regulators face and in so doing, shall introduce the concept of 'regulatory gifting'. I aim to demonstrate that regulatory gifting is a useful conceptual framework for understanding a particular form of government-led deregulation presented as central to the public interest. Contra to theories of regulatory capture, government corruption or 'insider' profit-seeking, regulatory gifting describes regulatory reform which is overtly designed by Government to reduce or reorient regulators' functions to the advantage of the regulated and in line with market objectives on a potentially national (rather than industry-specific) scale. Furthermore, the regulatory gift, consisting of four component parts (public narrative, reduction objective, corrective justification, dynamic function) is promoted by Government as countering regulation failures such as regulatory capture or democratic deficits. The features of the regulatory gift framework have been observed from analysing the characteristics of the regulatory landscape of democratic state economies and considering the adequacy of existing accounts of regulator vulnerability and its impact on the public interest. Whilst the concept of regulatory gifting is intended as generalisable, in this article the focus will be on the recent major regulatory reform in the UK which affected some 900 regulatory public bodies (the Public Bodies Act 2011 and its correlative legislation, the 2014 Regulator's Code, the Deregulation Act 2015, and the Enterprise Bill 2016) and the specific example of one such regulatory public body, the Human Fertilisation and Embryology Authority (HFEA).

What follows is organised into five main sections. The first provides a brief account of regulatory capture which holds prominent place in contemporary regulation studies for describing regulatory failure as well as other regulation theories which focus on the public interest. Set against these and influenced by a simple idea from anthropological studies - that the 
'gift' is a gesture of intent - the second section will introduce the conceptual framework of the regulatory gift. Here the combined features of the regulatory gift are offered as an alternative framework for describing a particular form of government-led deregulation. In the third section, regulatory gifting is considered in the empirical case of major regulatory reform in the UK, followed by a discussion of both how the regulatory gift depends on minimal understandings of the public interest and what a more substantive account might mean. Finally, the specific example of the public body responsible for protecting the public interest in the context of reproductive technology services in the UK, the HFEA is considered using the regulatory gift framework. The article concludes that whilst the regulatory gift may well align with the public interest in numerous cases - delivering on cost reduction, enhancing efficiency and stimulating innovation - this will not always be the case. Contrary to objectives, the regulatory gift has considerable potential to compromise the public interest as evidenced by the particular example of the HFEA.

\section{Regulatory failure and regulatory capture}

"The idea of regulatory capture has controlled discussions of...regulatory reform for more than two generations" (Novak, 2014, p25).

The dominant scholarly perspective on regulatory failure is informed by 'capture theory' and its many variations. Carpenter and Moss's (2014) definition of generic regulatory capture is perhaps the most clear: "the result or process by which regulation... is consistently or repeatedly directed away from the public interest and toward the interest of the regulated industry, by the intent and action of the industry itself' (op.cit. p13).

Early capture scholarship beginning in the US with the likes of Huntingdon (1953), Bernstein (1955) and later developed by Stigler (1975), Peltzman (1976) and Becker (1983), was weighted towards the idea that "policymakers are for sale, and that regulatory policy is largely purchased by those most interested and able to buy it" (Carpenter and Moss 2014, p9). However, beyond corruption, ${ }^{1}$ the majority of scholarship has moved its focus to more subtle forms of capture ${ }^{2}$ as

\footnotetext{
${ }^{1}$ See also the World Bank which used the term 'state capture' to mean a form of corruption defined as "the efforts of firms to shape and influence the underlying rules of the game (ie legislation, laws, rules and decrees) through private payments to public officials" (World Bank, 2000, p6). There is a similar theme in the Bootlegger and Baptist theory of regulation (see Yandle 1983).

${ }^{2}$ See Carpenter and Moss's excellent collection of essays on capture theory for a detailed discussion of the sub-categories mentioned here (Carpenter and Moss 2014).
} 
demonstrated, for example, by Sir Mervyn King, Governor of the Bank of England during the global financial crisis of 2008;

"One of the major problems in regulation in the last 10-20 years has been that of regulatory capture. By that I don't mean that people were bought off. What I mean is that the sheer weight of resources, time and legal efforts that was put in by banks to try to persuade regulators that what they were doing was compliant with the rules made life extraordinarily difficult for the regulators" (King 2011). ${ }^{3}$

This more amorphous form of regulatory capture comes in many variations including for example, 'Information Capture' whereby regulators are bamboozled by the technical detail of the industry they regulate and so become dependent on industry expertise in such a way that compromises their independent regulatory capacity (McCarty 2014, Wagner 2010); 'Economists' Capture' whereby scholars are seduced by industry to favour its own interests (over those of the public) thereby creating a bias which in turn is repeated by regulators who rely on scholars' pronouncements (Zingales 2014); 'Cognitive Capture' describes a sort of 'group think' that regulators adopt because prestige is associated with a certain trend of thinking in 'cutting-edge' industry (Johnson and Kwak 2010) or when regulators are encouraged to rely on problemsolving toolboxes which are much the same as those of the regulated industry (Needham 2010). 'Cultural Capture' (sometimes called 'Social Capture') whereby regulators are influenced by the industry they are responsible for regulating through working and socialising closely together creating a culturing process to industry's advantage (Kwak 2014) and when 'Cultural Capture' is used specifically for the purpose of stretching the interpretation of rules or promoting deregulation in the interests of industry ${ }^{4}$ then it becomes 'Corrosive Capture' (Carpenter 2014).

In sum, all of these capture approaches to understanding the failings of regulators have a primary feature in common - that regulators are vulnerable to being 'turned' or as Posner (2014, p49) describes 'subverted' by the industries they regulate.

In addition to regulatory capture theories, contemporary public choice scholars such as Zuplan (2017) and Shamoun and Yandle (2016) have focused on governmental insiders. This work has highlighted cases where, for example, governmental actors sought to align their interests with that of industry in order to seek profit or further their own personal interests and in doing so

\footnotetext{
${ }^{3}$ Also see, for example, Baker (2010).

${ }^{4}$ Early capture theory was predominantly interested in industries' desire to procure 'entry-barrier capture' (see Stigler 1974) rather than deregulation as is more the case with contemporary forms of capture theory (see Carpenter 2014).
} 
reformed specific regulations at the expense of the public interest. In this article, however, I want to focus on a different aspect of regulator vulnerability which is intentionally and publicly created by Government and which I shall call 'regulatory gifting'. My suggestion is that regulatory gifting is a particular model of state-level deregulation which is justified as being in the public's interest but as shall be illustrated, has, in some cases, the potential to undermine it. In the following section, the features of regulatory gifting are set out and the ways in which this framework differs conceptually from regulatory capture as well as other accounts such as governmental corruption and insider profit-seeking are outlined.

\section{Regulatory Gifting}

Rather than focusing on the capture of the regulator, the concept of 'regulatory gifting' describes a form of gift from Government to industry through a particular kind of de-regulatory reform at the state level. As anthropologists of 'the gift' explain, gifts are rarely neutral. Indeed, the gift often acts as a display of aspirations for closer alliances or a calculated gesture intended to secure particular interests. In selecting (or designing) and presenting a gift, the gift-giver accrues an agentic status that requires engagement. Should the gift be of positive value, a relationship of reciprocity develops, not necessarily in material exchange but one in which the gift-receiver's status of being identified as worthy of the gift is reflected in their confirmation of the gift-giver's 'wise decision' to select them as the subject of the gift. That is to say, there is a reciprocal affirmation through which the interests of each are directed and effected. The affirmation between gift-giver and recipient may be observable to others and the public visibility becomes a significant characteristic of the gift-giver-recipient relationship, shaping roles, declarations and the nature of the gift itself (see for example Peebles 2010, Laidlaw 2000, Maus 1990, Strathern, 1992, Schieffelin 1980).

The regulatory gift - a gift from Government to industry in the form of regulator restraint, reorientation or reduction - is not straightforward deregulation. It is a more complex process and has four observable constitutive features:

1. Public Narrative - regulatory gifting is an overt public gesture by Government to constrain regulators' impact on industry and a conspicuous signalling of alliance with industry interests.

2. Reduction Objective - the principle objective of the regulatory gift is to reduce regulation, on the grounds that regulation inhibits economic performance. 
3. Corrective Justification - the justification for the regulatory gift is presented as a fix for, for example, 'democratic deficit' in form of 'quango inefficiency', 'lack of transparency', 'restrictive barriers to market innovations' or regulatory capture.

4. Dynamic Function - the regulatory gift's functions are intentionally dynamic in that they effect substantial change in the regulator's capabilities over time and in doing so, the very ethos of the regulator is fundamentally altered in terms of its relation to the public interest.

Bearing these constitutive features in mind, the concept of regulatory gifting differs analytically from regulatory capture in three fundamental ways. The first is the direction of intent. As Carpenter (2014, p63) clarifies, regulatory capture occurs through "action and intent by the regulated industry" whereby "ultimate policy is shifted away from the public interest and toward industry interest". Regulatory gifting however does not rely on any particular regulator's action or intent to favour industry interests over those of the public. Rather the intentional direction is from Government to industry on a general scale and is overtly presented as being in the public's interest. The second distinction regards the public nature of the gift. Regulatory gifting not only establishes a reciprocal relationship between Government and industry but also acquires a political significance in terms of the government's perception (as the gift-giver) in the eyes of the public. In the specific example of regulatory gifting that I shall consider further on (through the UK's 2011 Public Bodies Act) and subsequent correlative legislation (such as the Deregulation Act 2015 and the Enterprise Bill 2016 ), this significance is manifested in the acquisition of a particular status in that the gifting is intended to inspire a positive reputation for Government as one that can be, for example, 'trusted with managing the economy', which 'understands the bigger economic picture best' and by cutting red tape, for example, it can 'help industry to create new jobs and ultimately to grow a stronger economy'. Industry's response is to endorse and congratulate the Government on its decisions and in so doing, further consolidates the Government's image of economic competence which, in turn, increases the perception that the public interest is being met. Unlike capture, the regulatory gift is openly presented as working for the public interest by addressing inefficiency, opacity and other common regulatory public body dysfunctions. The third difference between regulatory capture and regulatory gifting is scale. Government has the agency to affect change on a macro scale across the entire regulatory landscape as opposed to regulatory capture which is concerned more with the creation of tweaks and the opening up of gaps in the behaviour and remit of individual regulators.

Bearing these distinctions between capture and gifting in mind, we can also see how the regulatory gift differs from public choice based arguments such as government corruption or 
"insider interests". In the work of Zupan (2017) for example, individual government officials profit at the expense of the public interest. In a similar vein, Shamoun and Yandle's (2016) claim that a Head of State may be personally responsible for withdrawing or imposing particular regulatory reviews which benefit certain important political supporters for their own political gain. ${ }^{5}$ Whilst these concepts have some elements in common with regulatory gifting in that it is through the agency of the Government that the reform is initiated, they differ importantly in terms of how the activities of government officials are pursued covertly and operate on an industry-specific scale. ${ }^{6}$

Whilst this article will focus on a fine-grained analysis of UK regulatory public body reform through the conceptual framework of regulatory gifting, it is a framework intended to be generalisable to other examples in democratic-state markets. One such example follows a pledge by President Trump in the US, (which as we shall see further on is very similar to recent reform in the UK): " $[\mathrm{M}] \mathrm{y}$ administration will immediately pursue the following....to clean up the corruption and special interest collusion in Washington DC:.. a requirement that for every new federal regulation, two existing regulations must be eliminated...”" (Trump 2016). This manifested into Executive Order 13771 (2017) 'Reducing Regulation and Controlling Regulatory Costs' in the form of a blanket regulatory cap for the fiscal year of 2017. We have yet to see the detailed results of this Executive Order but even in this simple outline we can begin to detect the four elements of regulatory gifting - the overt public narrative gesture to the private sector, the explicit reduction objective which seems to override any normative questions relating to what a specific regulation (or regulator) is for, the corrective justification which indicates the built-in assumption that the quantity of regulation is the problem resulting in "corruption and special interest collusion" rather than the quality of regulation and how well it is functioning to protect

\footnotetext{
${ }^{5}$ The 1970s literature on structural power has some similarities to the regulatory gift ideaparticularly Lindblom's (1977) idea of 'exchange' between business and government. The fundamental claim in Lindblom's work is the positive relationship between business investment, GDP and public voting behaviour. This is certainly not inconsistent with the regulatory gift but Lindblom's focus is on the power that certain businesses have over Government e.g. their threat to disinvestment which is not a specific element of the regulatory gift. Similarly, with reference to the traditional Public Interest Theory (eg Pigou 1932), which focuses on the introduction of public policy in response to public demand, the regulatory gift differs in its direction (government to industry) and scale.

${ }^{6}$ Analytically then, the distinction between gifting and other concepts of regulatory vulnerability is sharp but in practice, it may be a challenge to distinguish the exact nature of agency or intent for example, but this is a general empirical difficulty in analysing regulation.
} 
the public interest. Finally, the dynamic function manifests in the rudimentary 'One In, Two Out' metric set on a federal scale which will inevitably have a considerable impact on the behaviour of regulators who will find themselves under increased threat of abolition in a 'regulation numbers game'.

My intention in this article is to suggest that the concept of regulatory gifting helps us give a particular reading of a complex form of Governmental regulatory reform. To demonstrate my argument in the next section, I will frame recent major public body reforms in the $\mathrm{UK}^{7}$ in terms of regulatory gifting.

\section{Regulator Reform in the UK and regulatory gifting.}

"We said we would increase transparency and accountability, cut out waste and duplication, and we have. ..... the quango state ${ }^{8}$ will never again be allowed to spiral out of control" (Maude, 2011a, p2).

Dommett and Flinders (2015) describe the UK as operating through a system of delegated governance or a 'hub model' whereby "a small strategic departmental core exists at the centre (or 'hub') of a vast range of arm's-length implementation mechanisms... [creating] "an increasingly complex and fragmented public sector that exists beyond the direct control of elected politicians"' (p1). 'This, as Levi-Faur's work has shown, can create a 'democratic deficit' in virtue of the power and public resources that regulators wield some distance from governmental departments (Levi-Faur, 2011). However, whilst "much maligned" as "unaccountable, profligate and bureaucratic" (Dommett, et al, 2014, p134), regulatory public bodies at the national level are considered by many as a "necessary evil" (Levi-Faur 2011, p15) as the nature of regulation becomes more complex and demanding (due to, for example, hi-tech developments or increasingly complicated international legal compliance laws etc). As the Institute of Government (2010) explain, public bodies “not so affectionately known... as 'quangos', are now fundamental to the effective running of the British state" (p10). This incongruity between necessity and unpopularity is what Gash and Rutter (2011) term the 'quango conundrum' (p95) and is reflected

\footnotetext{
7 The reforms under review in this article were introduced in the Conservative/Liberal Democrat Coalition Government (2010-2015) led by Conservative David Cameron as Prime Minster, followed by a Conservative Government again led by David Cameron (2015-2016) and most recently the Conservative Government led by Teresa May (July 2016 - current).

8 'Quango' refers to a quasi-autonomous non-governmental organisation. It is a term often expressed negatively to mean a bureaucratic, minimally accountable body resourced by the state.

${ }^{9}$ See Cabinet Office (2016) for full description of the various categories of UK public bodies (or ALBs arms-length bodies).
} 
in the contradictions of the first sentences of the introductory paragraph of the UK Cabinet Office's latest report on public body reform:

"Public bodies play a vital role in the delivery of public services and government priorities and are the most common interface between the public and government. The work to streamline public bodies, reduce costs and improve transparency and accountability is our priority" (Cabinet Office 2016, p1).

Such 'streamlining' began in earnest in 2011 with the introduction of the Public Bodies Act, (later to be accompanied by its correlative legislation - the 2015 Deregulation Act and the 2015 Enterprise Bill). Prior to 2011, it was a commonly held cross-party view in Westminster that the UK, with over 900 regulatory public bodies, had become a 'quango state' and governance reform was urgently needed (Gash and Rutter, 2011). ${ }^{10}$ Finally, the Conservative-led Tory-Liberal Democratic Coalition Government (2010-15) set up a review into regulative public body reform with Francis Maude (Conservative Cabinet Office Minister) at the helm. Drawing on the dominant language of regulation scholarship, the aim of the review was set "to reinvigorate the public's trust in democracy and also ensure that the Government operates in a more efficient and business-like way" (Cabinet Office 2010, p1). As we shall see, the tone of the public narrative around the new review was couched very much in terms of a reduction objective and with a strong corrective justification in the public interest.

Maude promised radical change and the eventual result was the 2011 Public Bodies Act which empowered ministers to abolish or reform public bodies in the UK. In order to guide ministers' decisions on the question of whether or not a given public body should be permitted to survive, Maude designed three tests: "A body should only exist as a quango if it meets one of three tests... These tests are: 1 . Does it perform a technical function? 2. Do its activities require political impartiality? 3. Does it need to act independently to establish facts?” (Maude 2011 p1-2). Whilst seemingly sensible questions to ask of a public body, as a mechanism for public body reform, this approach gave rise to an unprecedented consolidation of power by Government to reshape the regulatory landscape of the UK in that it enabled ministers to use the results of the tests to bypass parliamentary debate before abolishing, merging or modifying public bodies,

\footnotetext{
${ }^{10}$ See also Dommett, Flinders, Skelcher and Tonkiss (2014, p9) for example, who explain how "the abolition in 2003 of quinquennial reviews used to review ALBs "was seen to have created a governance vacuum in which neither departments nor central government were consistently regulating public bodies".
} 
many of which had come into being as a result of extensive parliamentary debate and deliberation.

By 2015 the Cabinet Office of the UK Government reported that through its Efficiency and Reform Group (ERG) which is charged with saving money and transforming the way public services are delivered through the Public Bodies Act 2011, it had already accomplished the significant saving of $f^{3}$ billion by radically reducing the number of public bodies (Cabinet Office 2015, p3). Indeed, 290 had been abolished, a further 165 public bodies were merged into fewer than 70 and the functions of over 50 further public bodies were moved out of the public sector, "into innovative new models" (op.cit. p4). Such models chime with the ERG's slogan "Government is open for business" (ERG 2014) and several public body functions have been moved to the private sector.

Also in 2015 and congruent with the Public Bodies Act 2011, the UK Government published Fixing the Foundations: Creating a more prosperous nation - a set of policy objectives to be pursued with "urgency and pace" (HM Treasury, 2015 p1). Key to these objectives was the creation of "[o]pen and competitive markets with the minimum of regulation. The UK's open and competitive market economy leads the world, but there is no room for complacency... in fighting stifling regulation" (op.cit. p12).

In line with these objectives the UK Government introduced considerable legislation to complement the Public Bodies Act 2011 (The Regulator's Code 2014, The Deregulation Act 2015, The Enterprise Bill 2016) all with the aim of reducing regulation further still but through complex and much more subtle means than Maude's public body tests. Through the Enterprise Bill 2016, Government emphasised its aim of "extending the scope of our deregulation target to cover the actions of regulators, going further than ever before to tackle troublesome red tape" (Department for Business, Innovation and Skills 2016c, p1). Under the new Bill, the Business Impact Target (BIT) ${ }^{11}$ which requires ministers to assess the economic impact of regulators' activities on businesses was set out. Overseen by a body called the 'Reducing Regulation SubCommittee of the Cabinet' ministers are also required to publish progress according to set deregulation targets. Accordingly, a 'One in, Two out' rule was introduced whereby regulators who create new regulation which renders a cost to business must modify existing regulation to the value of $£^{2}$ of savings for every $£^{1} 1$ of new cost imposed (Department for Business, Innovation and Skills 2016b). Indeed, "Government has never been more serious about reducing

\footnotetext{
${ }^{11}$ First introduced in the Small Business, Enterprise and Employment (SBEE) Act 2015 which did not originally cover the HFEA.
} 
the cost of regulation to business... these measures will help to reduce those regulatory burdens that hold firms back" (op.cit, p4). To this end, the first BIT Annual Report (2016) states that a further $f_{10}$ billion has been set as the new target of savings through restricting regulation and as part of that effort, "we have raised the bar within Government by enhancing One-In-Two-Out to a One-In-Three-Out rule across Government to help drive the deregulation" (Department for Business, Innovation and Skills 2016a). Here lies an example of the dynamic function of the regulatory gift reform. Having culled the 'low hanging' public bodies through the 2011 Public Bodies Act, the BIT metric fundamentally alters the capabilities and ethos of those remaining (as we shall see in the case study of the HFEA further on).

Beyond the BIT measure, other examples of the dynamic functions of this particular regulatory reform include the Regulator's Code (2014) - a "framework for regulatory delivery that supports and enables regulators to design their service and enforcement policies in a manner that best suits the needs of businesses” (Department for Business, Innovation and Skills, 2014, p2) and which calls for the following; "When designing and reviewing policies, operational procedures and practices, regulators should consider how they might support or enable economic growth" (op.cit.p3). An even stronger example of a dynamic function is the Growth Duty. First introduced in the Deregulation Act 2015, the Growth Duty places a specific requirement on regulators to "have regard to the desirability of promoting economic growth in the exercise of that [regulatory] function" (sections 108 and 110, Deregulation Act 2015). As the Department for Business, Energy and Industry Strategy ${ }^{12}$ (2016) recently reported "[T] he growth duty clearly establishes Government's expectation that economic growth is an outcome that all regulators should be working towards" (op.cit: p1) and that regulators must build an approach to delivering regulation that can "assist in creating a more dynamic business environment, supporting innovation" (op.cit: p7).

Together these measures require regulators to continuously document the views of businesses on the effect that regulation has had on business capabilities and include these views in their performance reports. These, in turn, become a key feature in the triennial review of each regulatory public body. In the words of Maude, the triennial reviews "will not only make sure that quangos whose functions are no longer needed don't remain, but the reviews will also encourage bodies to explore new models of delivery and to drive through even more efficient

\footnotetext{
${ }^{12}$ The Department for Business, Innovation and Skills became the Department for Business, Energy \& Industrial Strategy in July 2016 under the new Prime Minister, Teresa May took over as Leader of the Conservative Party in Government.
} 
ways of delivering public services" (Maude, 2011a p1). In effect, in order to survive, a regulatory public body must show, not only how it does not hinder business interests but how it actively facilitates business.

In sum, these public body reforms clearly demonstrate the characteristics of regulatory gifting. As we have seen, the statements of Maude, the Cabinet Office, Department for Business, Energy and Industry Strategy as well as the correlative wording of the various Acts aimed at public body reform, all demonstrate a very public narrative by Government explicitly setting out its designs for serving industry. Within these expressions of intent, our attention is drawn to the reductive objective of 'unburdening industry' and 'minimising regulation to unleash ever more competitive markets'. Similarly, we can observe the corrective justification for radical public body reform - the 'slashing of quangos' resulting in the 'saving of billions of pounds' is presented as a fix for wasting public money on public bodies, for giving too much power to non-elected regulators resulting in a democratic deficit and the potential for regulatory capture. Finally, the dynamic functions manifest in the various tools that ministers are empowered with through these reforms - the Regulator's Code, the BIT and the Growth Duty. These three particular requirements - to follow a corporate-oriented code, to ensure savings amounting to triple of that incurred by the regulated and to be monitored on Growth Duty criteria - are all bound to have a fundamental reorienting effect on regulators' practices and ethos especially under threat of potential modification or abolishment through triennial review. Indeed, as Dommett and Flinders (2015, p17) argue "the shadow of hierarchy... has grown significantly darker for public bodies in the UK" and what was once an arm's length relationship with Government is now more of an "arm-lock" (ibid). Having described these reforms through the characteristics of the regulatory gift framework, how convincing are they in terms of the public interest? This is the focus of the next section.

\section{Public Bodies, Public Interest and the Regulatory Gift}

" $[t]$ he assumption behind governmental regulation is the possibility of protecting the public interest against private, especially business, interests" (Christensen 2011, p96).

Inherent to the regulatory gift is the concept of the public interest. The public nature of the regulatory gift is such that the gift must appeal not only to industry but also to the public. But for the public to accept that the gift will indeed bring benefits beyond its immediate consequences for industry, requires more than the insistence of Government that this is the case. This is where the reciprocal nature of the gift comes into force. As Government announces its intentions, industry responds and affirms that the claims that are made for the gift are indeed true. It is vital 
that industry endorses and supports the gift as it is this support which confers on the government the mantle of economic competence and is crucial to justifying the gift as being in the public interest. For example, the Confederation of British Industry's $(\mathrm{CBI})^{13}$ response to the 2016 Enterprise Bill (containing the BIT) is as follows: "The Enterprise Bill includes important measures that should improve opportunities for growing businesses to get on and scale up...Pruning unnecessary red tape will give firms bursting with potential...the space to grow and thrive" (CBI, 2016, p1).

Simultaneously, just as Government looks to industry to support the gift, it also represents the alternative - of leaving regulators' remit as it is - as very clearly not being in the public interest. As we have seen, for instance, the UK Government's pronouncements on red tape reduction highlight a number of claimed inadequacies of regulators (democratic deficit in the form of lack of transparency and waste of public money). But this negative conception of regulation generates a tension between competing visions of what the public interest means. After all, it is also the case that the primary function, telos or what Warren (1999, p349) calls the "normative idea" of a regulatory public body, is to protect the public interest on the grounds that well thought-out regulation as a form of constraint on private interests is a positive practice which benefits society (O’Neill 2002).

One source of this tension is that the definition of 'public interest' has proved extremely elusive (see for example, Carpenter and Moss 2014, Goodin 1996, Levine and Forrence, 1990 Sorauf, 1957). As Croley (2007) explains unlike the narrow well-defined industry interests, the public interest is invariably wide and vicissitudinal. ${ }^{14}$ It is a concept that virtually by definition requires democratic foundations and yet how democracy is exercised in establishing what is in and what is not in the public interest is contentious. On the one hand, the 'democratic deficit' argument made in favour of regulatory gifting advances the view that the regulator's lack of elected status is, in and of itself, anti-democratic. But there is a counter-argument that the more specialised and technical the object of regulation is, the less likely it is that a politician is sufficiently knowledgeable to make informed decisions in the interests of the public (Mitnick, 2011) especially in the context of the very fine (but nevertheless impactful) details of regulation so rarely aired for debate in election campaigns. This is where the primary role of the regulatory public body comes into being - to bridge the expertise of the regulated field with the political and

\footnotetext{
${ }^{13}$ The CBI is the largest and most influential business organisation in the UK representing over 190,000 member firms which employ over 7 million people (see CBI 2016).

${ }^{14}$ See also Schwarcz (2014) whose work focuses the problem of collective action in regulatory processes and in particular considering the role of consumer power in counterweighting industry interests.
} 
practical objectives of politicians, whilst also taking into account the public's concerns through independent consultation and representation within the regulatory body. Such a structure needs to be carefully designed - the public body must be furnished with sufficient resources and must be able to make its decisions independently of political and profit-oriented objectives (a reason why self-regulation by industry is often unconvincing as being in the public interest).

A further source of tension in the debate over what constitutes the public interest lies in the difference between 'minimal' and 'substantive' accounts of regulators' functions. Whilst each public body must give a sufficient account of how it protects the public interest in particular terms (Carpenter 2014), in general terms at the very least, a public body must be able to minimise that which is clearly not in the public interest - for example, unsafe medical practices, corrupt practitioners, false advertising etc. Indeed, this minimal account of the public interest is deemed necessary for markets to function well by the majority of industry itself. A lack of public confidence in practitioners' credentials, abilities or the services they claim to be able to deliver is bad for business. Accordingly, a minimal conception of regulation is one in which market and public interests are aligned. At a more substantive level, however, the public body goes further, in anticipating, for example, the structural implications for society of the practices it regulates or the ethical issues that may arise from them and also making recommendations to Government on how best to reduce the public's vulnerability to more complex potential harms than those which arise simply from market mal-practice. ${ }^{15}$ Such a conception of a potentially positive role for regulation is at odds with the central tenet of regulatory gifting.

In order to consider these and other elements of the UK public body reforms through the lens of regulatory gifting in some more detail, let's now turn to the specific case of a prominent UK public body - the Human Fertilisation and Embryology Authority (HFEA) - by way of example. In the following section, I will first explain the importance of the HFEA in regulating reproductive bio-technologies and then go on to demonstrate how the four elements of regulatory gifting (public narrative, reduction objective, corrective justification, dynamic functions) have impacted on the HFEA.

\section{The HFEA}

A brief guide...

\footnotetext{
${ }^{15}$ See Kaldor-Hicks efficiency for an alternative account focused on regulatory benefits (Kaldor, 1939, Hicks 1939, Posner 1980).
} 
Concerned with the ethical and legal implications of in vitro fertilisation (IVF) technologies (first developed in the UK by Edwards and Steptoe in the 1970s), ${ }^{16}$ the UK Human Fertilisation and Embryology Authority (HFEA) was established as a statutorily independent Non-Departmental Public Body (NDPB, meaning that it operates independently from Government but ultimately is answerable to its host governmental department - the Department of Health) under the Human Fertilisation and Embryology Act 1990 (amended 2008). ${ }^{17}$

One of the HFEA's primary functions is to license, monitor and regulate provision of all fertility treatments (such as IVF, gamete and embryo freezing and pre-implantation genetic diagnosis) and also any research involving the use of human gametes and embryos in the UK. ${ }^{18}$ For example, the HFEA prohibits the implantation of non-human embryos or gametes or admixed embryos (part human part non-human embryos) ${ }^{19}$ in humans and also prohibits human cloning. ${ }^{20}$ As set out in the Warnock Report (1984, p75-79), the call for such a public body rested on the understanding that "public concern about the techniques.. [involving gametes and embryos] needs to be reflected in public policy", that "the protection of the public, which...[is] the primary objective of regulation, demands the existence of an authority independent of Government, health authorities, or research institutions" and that such a body must not be "unduly influenced by sectional interests". This tells us much about the telos of the HFEA. Aside from licensing and regulating research institutions and fertility clinics, another core function of the HFEA is to provide advice to Government for legislation, policy and the dissemination of reliable information on the usages of reproductive technologies and research etc. This is a vital public service which, while in consultation with the industry it regulates, is nevertheless intended to be independent of its profit-oriented objectives. The HFEA is charged with making (what are sometimes highly controversial) recommendations to Government in the public interest. It does this through expert working-groups and also public consultation which draw responses from individual members of the public, lay groups (members of public who have held local discussion groups), religious groups, professional bodies, research and clinical institutions etc. Once the HFEA has analyzed responses generated by public consultation on a given topic and reviewed the various implications of the potential of the biotechnology in

\footnotetext{
${ }^{16}$ Robert Edwards and Patrick Steptoe performed the first successful IVF procedure (leading to the birth of Louise Brown in 1978) at the Bourn Hall Clinic in Cambridgeshire. Edwards was later awarded the Nobel Prize for medicine in 2010.

${ }_{17}^{17}$ The 1990 Act was largely based on the 'Warnock Report' (1984).

18 A detailed account of HFEA duties can be found in HFEA (2016d) p7-8.

${ }^{19}$ See No.4 of the Human Fertilisation and Embryology Act 2008.

${ }^{20}$ See the Human Reproductive Cloning Act 2001.
} 
question, it then makes an informed recommendation to Government and subsequently acts as the main source of information for parliamentary debate. Recent examples of this process include the ethically sensitive decision to recommend to Government, that under strict regulation, licensed clinics should be permitted to perform pro-nuclear and maternal spindle transfer for serious hereditary mitochondrial disease. ${ }^{21}$ These techniques involve moving nuclear DNA from an egg or embryo containing unhealthy mitochondria to a donor's egg or embryo containing healthy mitochondria (from which the nuclear DNA has been removed) to produce offspring free from mitochondrial disease (provocatively dubbed 'three parent babies' by the press). This was a contentious recommendation but such was the confidence of all those formally involved that the HFEA had conducted the most thorough and constructive consultative process with both experts and the public and most importantly, was competent in rigorously regulating such techniques in the UK, that the Government translated the HFEA recommendations into law in 2015. ${ }^{22}$ Similarly in 2016, after extensive consultation, the HFEA granted a licence permitting the Francis Crick Institute in London to use the new gene editing technique CRISPR-Cas $9^{23}$ under strict regulated (in vitro) conditions to better understand embryo development and miscarriage. This makes the UK the only country (outside of China) to permit gene editing research (HFEA 2016e, p1).

As the HFEA stated in its recent Innovation and Regulation report, "[ $t$ ]hese groundbreaking developments have happened because of the regulation not in spite of it. The Human Fertilisation and Embryology Acts 1990 and 2008 and the HFEA have provided a stable, yet flexible, framework in which UK bio-science and clinical expertise have been able to flourish. Scientists and clinicians have been able to go about their work free of the 'culture wars' that have hampered such activity in the USA or the regulatory free-for-all of much of the Far East." (HFEA 2016e, p1, emphasis added). The point to be made here is that good regulation cannot be said to stifle innovation, rather it is a vital part of it, if it is to remain linked to the public interest.

The HFEA was the first statutory body of its kind and is internationally acclaimed as a regulative authority on reproductive technologies and embryology. Indeed, Franklin describes the HFEA as "nothing short of a national treasure" (Franklin 2013b, p4). ${ }^{24}$

\footnotetext{
${ }^{21}$ See HFEA 2014 for more details on Mitochondria.

22 See Human Fertilisation and Embryology (Mitochondrial Donation) Regulations (2015)

23 See Human Fertilisation and Embryology Authority (2016f)

${ }^{24}$ Similarly O'Neill (2002) describes the HFEA as having "earned high respect" (p127).
} 
The technological ability to harvest human eggs, screen, alter and fertilize them outside of a woman's body before implantation, has not only changed the parameters of human reproduction but has expanded the research and future market possibilities of regenerative medicine, cloning, preimplantation genetic diagnosis and engineering and even human-animal chimeras (Franklin, 2013b). These, without any doubt, will have profound transformative effects on human life in the future and surely must be the subject of vigilant and well-resourced regulation in the interest of the public.

\section{The HFE $A$ and Regulatory Gifting.}

In line with the very public narrative of what I have called here the reduction objectives of regulatory gift reforms, the Government had intended, under the 2011 Public Bodies Act, to abolish the HFEA once its duties were fused with those of the Human Tissue Authority and transferred to the Care Quality Commission under the Public Bodies Act. However, passionate political debate ensued across the Houses of Parliament and in public ${ }^{25}$ and the HFEA survived. ${ }^{26}$ However, like all other remaining public bodies, it is subject to a substantive triennial review which has two defined purposes: 1) "to provide a robust challenge of the continuing need for individual NDPBs, both their functions and their form"; 2) "where it is agreed that a body should remain as an NDPB, to review... and ensure that the public body is complying with recognized principles of corporate governance" (Cabinet Office 2014, p9). The tone of the triennial reviews is aggressive and the (ministerial level) reviewer is required to "provide evidence and rationale" for maintaining public body status for each regulator. This means, in short, that at least once in every three years, the HFEA must demonstrate its alignment with the reduction objective and corrective justification aspects of the Public Bodies Act or risk abolition. It is worth noting here that the legislation through which the HFEA and its framework was created "clocked up between them a total of more than 100 hours on the Floor of both Houses of Parliament, not counting any pre-legislative scrutiny debates or Select Committees involved..." (Thornton, 2010, Column 155). Similarly, Harries (2010, Column 111) argues, "If Parliament has thought this area so critical that it was worth weeks of its time to set up a regulatory body with very tight regulation

\footnotetext{
25See for example discussion of the Public Bodies Bill 2010 in the House of Lords on 28th October 2010. http://www.publications.parliament.uk/pa/ld201011/ldhansrd/text/1010280001.htm\#10102834000816 Also see for example the McCracken review (McCracken 2013) and the HFEA's discussion of it (HFEA 2013).

${ }^{26}$ See for example 'Human Fertilisation and Embryology Authority' p57, Public Bodies Reform Programme Update, 1 December 2015. https://www.gov.uk/government/uploads/system/uploads/attachment_data/file/506070/Annex Public Bodies Reform_Programme Update 16_Dec 2015.pdf
} 
in place, it hardly seems responsible to dismember that body with one quick snip and without serious consideration of the implications of so doing", and Judd (2011) who states; "There are puzzling contradictions in the Government's overall position. The Government keep emphasising that they want to improve the quality of democracy and to reduce the size of what they like to call the state. They say that they want to bring power and decision-making closer to the people. How such concentration of wide-ranging powers in the hands of Ministers will help to achieve those objectives is to me - and, I think, to most people - a total mystery" (Column 141). Here again, it is not at all clear that the Public Bodies Act delivers a solution to democratic deficit but rather reduces the possibility of democratic debate on some of the most important national regulatory functions.

As of yet, the HFEA has retained its functions albeit reframed through the Regulator's code, the BIT and the Growth Duty. However, the possibility of its functions being transferred to the private sector remains open under the terms of the Public Bodies Act (schedule 5). Of particular note here is the argument made by Dommett et al (2014 p141) regarding the transference of powers to the private sector. They point out that there is no requirement on the private sector to be transparent about "the public money they receive, since this is regarded as commercially sensitive.... The contracts government has with private companies are private". In terms then of core corrective justifications for the regulatory gift, such as the claims that it will reinvigorate "the public's trust in democracy" (Cabinet Office 2010, p1) and "increase the transparency and accountability" of regulatory practices (Maude 2011a, p1), what would seem to be more likely is much weaker democratic practices and the potential for far more opacity. ${ }^{27}$

Regarding the specific dynamic functions of these regulatory gift reforms, let's now turn to the potential impact of the BIT. The majority of the HFEA's funding $\left(79 \% 0^{28}\right)$, is generated from the fees it charges the clinics and research establishments it regulates (whilst Government funding through the Department of Health only provides $21 \%{ }^{29}$ of HFEA's income). The HFEA disclosed that it is running a deficit of $f_{885,483}$ (HFEA 2016, p18) and is subject to a continued recruitment freeze with staff numbers at 66 (op.cit, p34). This is an institution under strain both financially and in terms of human resources (op.cit, p27). It is required, on the one hand, to generate more funds from clinics and research institutes but at the same time to demonstrate

\footnotetext{
${ }^{27}$ An alternative view on transparency altogether comes from Cass Sunstein who has recently argued that "input transparency" ie who talked to whom before rules and regulations are written is over emphasised in terms of the public interest. His argument is that it limits candour and in some cases the motivation to discuss issues at all (Sunstein 2017).

28 Amounting to $£ 4,215,000$ for 2015/16 (HFEA 2016, p18).

29 Amounting to only $£ £ 1,120,000$ for 2015/16 (HFEA 2016, p18).
} 
how it is not a financial burden on businesses. The requirement that the HFEA must adopt the Growth Duty has also generated concern. In a House of Lords debate for example, Hunt (2015) argued that the Growth Duty is at odds with the legislation on which the HFEA's functions are based and determined "[t]here is no provision in the Human Fertilisation and Embryology Act for the HFEA to have regard to the imperative to promotion of economic growth when making its decisions. If a clinic does not meet statutory requirements it cannot grant a licence or allow a certain activity to take place, regardless of how economically desirable it might be thought to be" (Column 1237). Winston (2015) expressed concern that ever -growing commercialisation of fertility treatments was at the heart of the Government's approach which would "encourage what is already a disgraceful [fertility] market" (Column 1238). ${ }^{30}$ Similarly, in the Government's recent 'call for evidence' on the performance of the HFEA, one of the questions posed was; Q 8. "Could the Authority do more to support innovation and new approaches in the area of human fertilisation and embryology?" In answer, the Nuffield Council on Bioethics stated;

"No... As a regulator, the HFEA's role should not be to promote innovation and new approaches, since this raises a potential conflict with its essential purpose.....Insofar as the HFEA should be subject to any duty relevant to research and innovation, it should be to promote public good consistent with public morality and the protection of the interests of patients and their off-spring, not to promote research and innovation per se. We would have grave concerns if for example, an 'economic growth duty' (such as provided by s.108 of the Deregulation Act 2015) should apply to the HFEA. Such a duty would be either unnecessary (no regulatory action should be disproportionate with respect to the purposes of regulation) or pernicious (justified and proportionate action should not be modified in consideration of its economic impact)" (Department of Health 2016, p6).

In a recent Authority meeting (HFEA 2016b) the HFEA Board considered these measures likely to reduce the HFEA's "ability to enforce requirements robustly... [and that] a duty to promote growth... undermines the delicate balance that the HFEA has managed to strike... [between] the interests of science and innovation and society's concerns about the nature and pace of such developments". Here we can see the dynamic functions of these reforms at play in the case of the HFEA and it is perhaps not surprising that this public body counts "loss of regulatory authority" as one of its potential institutional risks in its last annual report (HFEA 2016, p15).

\footnotetext{
30 A view shared with Baroness Mary Warnock (Crossbencher and author of the Warnock Report (2015, Column 1239).
} 
The HFEA is of course not flawless and certainly has attracted a range of criticism. Several authors find fault with the limitations of the HFEA's legislative framework and consequently its capabilities (see for example Horsley 2015). From another angle, neo-eugenics ethicists such as Savulescu (2011) argue we, as a society, shouldn't attribute special moral status to the human embryo at all (a principle the HFEA remit is built on) and that accordingly the HFEA's attempts to work within "conservative morality" (op.cit. p1) hinders both scientific and social progress.

Whatever ones' views on the debates themselves however, it is difficult to imagine a better public body structure that serves the public interest in the context of embryology and reproductive sciences than Warnock's design of the HFEA; 31 "We would... envisage a significant representation of scientific and medical interests among the membership. It would also need to have members experienced in the organisation and provision of services...If the public is to have confidence that this is an independent body, which is not to be unduly influenced by sectional interests, its membership must be wide-ranging and in particular the lay interests should be well represented. We recommend that there should be substantial lay representation.... and that the chairman must be a lay person" (Warnock 1984, p2). Such a structure is not well aligned with the intentions of the regulatory gift reforms such as the Public Bodies Act and its correlative legislation.

\section{Concluding Remarks}

"[E]fforts to deregulate must be held to the same level of scrutiny as efforts to regulate in thinking about the potential costs and benefits for the public as a whole" (Carpenter and Moss 2014b, p70).

As we have seen, most regulation scholarship on regulator vulnerability has focused on the ways in which industry seeks to subvert or capture regulators so as to further industry interests or that governmental insiders align themselves with industry interest for personal gain. However, as set out in this article, I have tried to shed light on a different sort of political relationship in which the state itself is the agent and unilaterally enacts regulatory reform to the benefit of industry but not in response to any explicit (or covert) industry demand or in the pursuit of individual profitseeking - instead it is publicly claimed to be in the public interest. Analysis of this practice 'regulatory gifting' - offers a perspective which tends to be under-scrutinised in current regulation literature.

\footnotetext{
${ }^{31}$ See the Warnock Report (1984).
} 
In attempting to demonstrate that regulatory reform is indeed in the public interest, Government typically constructs a public narrative in which economic objectives are prioritised and in which regulation is seen as a barrier to achieving these objectives. With this in place, the Government's commitment to decreasing regulation (reduction objective) can be given various forms of corrective justification such as reducing 'red tape', increasing flexibility or boosting competitiveness. At a legislative level, Government delivers on this commitment by changing the framework through which regulation takes place (the dynamic functions of regulatory gifting). Often, this calls into question the 'normative idea' of the regulator and results not only in a reorientation of the means of regulation but also its very purpose.

In developing the theoretical elements of regulatory gifting, I have considered how these concepts apply to the particular example of recent UK public body reform. The context for these reforms was a widely perceived need or as Maude (2010, p1) describes it a "hunger" for review and change and as I have shown, the consequent reforms significantly reduced the UK's regulatory landscape. Whilst there was little doubt that public bodies ought to be regularly scrutinised (and in some cases abolished where regulatory gifting genuinely aligns with the public interest), the example of the HFEA provides a specific example of how regulatory gifting has the potential to significantly undermine the public interest. Because of the speed of scientific advances and the unpredictable consequences of these for society, the human fertility industry presents complex ethical challenges for the regulator which are not adequately addressed through the narrow economic criteria of the BIT, the Growth Duty or the Regulator's Code.

Furthermore, despite the corrective justification that typically accompanies regulatory gifting, that regulatory reduction is necessary to enhance democracy by addressing the 'democratic deficit', increasing transparency and reducing the risk of regulatory capture, the UK experience calls this claim into question. The UK public body reform bestowed ministers with the power to sidestep parliamentary debate on whether to abolish or modify key public interest arbiters and created a means by which public body duties and resources could be passed to the private sector where transparency is often a matter of discretion rather than public duty. Ironically, these elements of the regulatory gift reforms may well turn out to encourage regulatory capture as regulators become ever more dependent on the approval (and support) of the industries they regulate in order to survive.

In the current political context in which the reduction or removal of regulation is increasingly seen as a panacea for economic ills, the combined characteristics of what I have called here regulatory gifting are gaining in political appeal. Faced with this growing popularity and the 
greater likelihood that further attempts will be made to re-orient how we think of the purpose of regulation, it is of paramount importance that we consider regulatory gifting in context and carefully scrutinise its relationship to the public interest.

Acknowledgements: Sincerest thanks to Dr Umar Salam, Professor Jason Sharman, Dr Duncan Bell, Professor Mathew Gandy and also Professor David Levi-Faur, Editor of Regulation \& Governance as well as four anonymous expert reviewers for all their very helpful comments.

\section{Bibliography}

Baker, Andrew (2010) 'Restraining regulatory capture? Anglo-America, crisis politics and trajectories of change in global financial governance'. International Affairs, Vol. 86, Issue 3.pp 647-663.

Baldwin, Robert. (2008) 'Regulation Lite: the rise of emissions trading' Regulation and Governance. Vol. 2. Issue 2. pp 193-215.

Baroness Mary Warnock (2015). Deregulation Bill: Exercise of regulatory functions: economic growth. $11^{\text {th }}$ February 2015. House of Lords, Hansard Text: Column 1239.

http://www.publications.parliament.uk/pa/ld201415/ldhansrd/text/150211$\underline{0001 . h t m \# 15021191001285}$

Becker, Gary (1983) "A Theory of Competition among Pressure Groups for Political Influence," Quarterly Journal of Economics, vol. 98. pp. 371-400.

Becker, Gary (2011) Capture of Regulators by Fannie Mae and Freddie Mac. The Becker-Posner Blog. http://www.becker-posner-blog.com/2011/06/capture-of-regulators-by-fannie-mae-andfreddie-mac-becker.html

Bernstein, Marver, H. (1955) Regulating Business by Independent Commission. Princeton: Princeton University Press.

Cabinet Office (2010) Public Body Review Published. The Right Honourable Lord Maude of Horsham. UK Cabinet Office Press Release. London. HMG https://www.gov.uk/government/news/public-body-review-published 
Cabinet Office (2014) Triennial Reviews: Guidance on Reviews of Non-Departmental Public Bodies 201415. London: Cabinet Office, the UK Government.

https://www.gov.uk/government/uploads/system/uploads/attachment data/file/332147/Trie nnial Reviews Guidance.pdf

Cabinet Office (2015) Public Bodies 2015. London: Cabinet Office, the UK Government. https://www.gov.uk/government/uploads/system/uploads/attachment data/file/506880/Publ ic Bodies 2015 Web 9 Mar 2016.pdf

Cabinet Office (2016) Report on the Outcome of the Classification Review. London: HMG https://www.gov.uk/government/publications/classification-review-of-public-bodies-outcome$\underline{\text { report }}$

Carpenter, Daniel (2014) 'Corrosive Capture? The Dueling Forces of Autonomy and Industry Influence in FDA Pharmaceutical Regulation' in Daniel Carpenter and David, A. Moss, Preventing Regulatory Capture: Special Interest Influence and How to Limit it. Cambridge. University of Cambridge Press. pp 152-172.

Carpenter, Daniel and Moss, David, A. (2014) 'Introduction' in Daniel Carpenter and David, A. Moss (Eds), Preventing Regulatory Capture: Special Interest Influence and How to Limit it. Cambridge. University of Cambridge Press. pp 1-22.

Carpenter, Daniel and Moss, David, A. (2014b) 'New Conceptions of Capture - Mechanisms and Outcomes' in Daniel Carpenter and David, A. Moss (Eds), Preventing Regulatory Capture: Special Interest Influence and How to Limit it. Cambridge. University of Cambridge Press. pp 69-70.

Christensen, Jørgen Grønnegaard (2011) Public Interest Regulation Reconsidered: From Capture to Credible Commitment in David, Levi-Faur (Ed) Handbook on the Politics of Regulation.

Massachusetts: Edward Elgar Publishing. pp. 96-112.

Confederation of British Industry (CBI) (2016) CBI Comments on Enterprise Bill. London: CBI. http://www.cbi.org.uk/news/cbi-comments-on-enterprise-bill/

Croley, Steven. (2007) Regulation and Public Interests: The Possibility of Good Regulatory Government. Princeton: Princeton University Press.

Department for Business, Energy and Industry Strategy (2016) Growth Duty S110 Guidance December 2016. HMG: London. 
https://www.gov.uk/government/uploads/system/uploads/attachment data/file/574499/gro wth-duty-statutory-guidance.pdf

Department of Business, Innovation and Skills (2014) Minister of State for Business and Enterprise. Regulator's Code. London: Better Regulation Delivery Office.

HMG.https://www.gov.uk/government/uploads/system/uploads/attachment data/file/30012 6/14-705-regulators-code.pdf

Department of Business, Innovation and Skills (2016a) Secretary of State for Business, Innovation and Skills. Business Impact Target: First Annual Report 2015-2016. Better Regulation Executive. Department of Business, Innovation and Skills. HMG: London.

https://www.gov.uk/government/uploads/system/uploads/attachment data/file/530683/bis16-182-bit-annual-report.pdf

Department of Business, Innovation and Skills (2016b) Secretary of State for Business, Innovation and Skills. The Business Impact Target, Growth Duty and Small Business Appeals Champion Consultation on scope and guidance. Department of Business, Innovation and Skills. HMG: London. https://www.gov.uk/government/uploads/system/uploads/attachment data/file/499442/bis16-94-bit-growth-duty-sbac-consultation.pdf

Department for Business, Innovation and Skills (2016c) Government going further to cut red tape by £10 billion. Press Release, 3 March 2016. Department of Business, Innovation and Skills. HMG: London.

https://www.gov.uk/government/news/government-going-further-to-cut-red-tape-by-10billion

Department of Health (2016). Response to the HFEA Triennial Review 2016: Nuffield Council of Bioethics. Department of Health. HMG: London. http://nuffieldbioethics.org/wpcontent/uploads/NCOB-response-to-HFEA-triennial-review.pdf

Deregulation Act (2015) UK Act of Parliament. London:

HMG.http://www.legislation.gov.uk/ukpga/2015/20/contents/enacted

Djankov, Simeon., Glaeser, Edward,. La Porta, Rafael., Lopez-de-Silanes, Florencio and Shleifer, Andrei. (2003) 'The New Comparative Economics', Journal of Comparative Economics. Vol. 31 pp $595-619$. 
Dommett, Katharine and Flinders, Matthew (2015) The Centre Strikes Back: Meta-Governance, Delegation and the Core Executive in the United Kingdom, 2010-14. Public Administration. Vol. 93, No. 1 pp1-16.

Dommett, Katharine., Flinders, Matthew., Skelcher, Chris., and Tonkiss, Katherine (2014) 'Did they 'Read Before Burning'? The Coalition and Quangos'. The Political Quarterly, Vol. 85, No. 2. P133-142.

Efficiency and Reform Group (2016) UK Government Cabinet Office, "Government is Open for Business" Efficiency and Reform Group Official Website (accessed 23 April 2016) https://www.gov.uk/government/organisations/efficiency-and-reform-group

Enterprise Bill (2016). House of Lords, UK Parliament. London: HMG.

http://services.parliament.uk/bills/2015-16/enterprise.html

https://www.gov.uk/government/uploads/system/uploads/attachment data/file/503155/bis15-694-enterprise-bill-bit.pdf

Franklin, Sarah. (2013a) Biological Relatives: IVF, Stem Cells and the Future of Kinship. London: Duke University Press.

Franklin, Sarah. (2013b) The HFEA in Context. Sarah Franklin.com.

http://sarahfranklin.com/wp-content/files/Franklin-The-HFEA-in-Context-2013.pdf

Gash, Tom and Rutter, Jill (2011) ‘The Quango Conundrum’, Political Quarterly, Vol. 82. No. 1. pp 95-101.

Goodin, Robert, E. (1996) 'Institutionalizing the Public Interest: The Defense of Deadlock and Beyond Author(s).' American Political Science Review. pp 331-343.

Harries, Lord Harries of Pentregarth (2010) Public Bodies Bill. $9^{\text {th }}$ November 2010. House of Lords, Hansard Text: Column 111.

http://www.publications.parliament.uk/pa/ld201011/ldhansrd/text/101109_ $\underline{0001 . h t m \# 10110950000414}$

Hicks, John .R.(1939). “The Foundations of Welfare Economics.” Economic Journal 49(196): 696-712.

HM Treasury (2015) Fixing the Foundations: Creating a more prosperous nation. Chancellor of the Exchequer CM9098. London: HMG.

https://www.gov.uk/government/uploads/system/uploads/attachment data/file/443898/Pro ductivity Plan web.pdf 
Horsey, Kirsty. (2015) (Eds.) Revisiting the Regulation of Human Fertlisation and Embryology. London: Routledge.

Human Fertilisation and Embryology Authority (HFEA) (2013) Authority Agenda Wednesday. London: HFEA. 13 November 2013. http://www.hfea.gov.uk/docs/2013-11-

\section{Authority Papers Complete.pdf}

Human Fertilisation and Embryology Authority (HFEA) (2014) Mitochondrial donation: an introductory briefing note Human Fertilisation and Embryology Authority, October 2014. London: HFEA http://www.hfea.gov.uk/docs/2014-10-

$\underline{01 \text { Mitochondrial donation an introductory briefing note - final.pdf }}$

Human Fertilisation and Embryology (Mitochondrial Donation) Regulations (2015) London: HMG. http://www.legislation.gov.uk/ukdsi/2015/9780111125816/contents

Human Fertilisation and Embryology Act $(1990,2008)$ UK Act of Parliament. London: HMG. http://www.legislation.gov.uk/ukpga/2008/22/pdfs/ukpga 20080022 en.pdf

Human Fertilisation and Embryology Authority (HFEA) (2016f) Licence Committee Minutes Thursday $14^{\text {th }}$ January 2016 http://guide.hfea.gov.uk/guide/ShowPDF.aspx?ID=5966

Human Fertilisation and Embryology Authority (HFEA) (2015) Annual Report 2014-15. London: HFEA. http://www.hfea.gov.uk/docs/HFEA Annual Report and Accounts 201415.pdf

Human Fertilisation and Embryology Authority (HFEA) (2015) Regulating mitochondrial donation: seeking expert views Background document. June 2015. London: HEFA http://www.hfea.gov.uk/docs/2015-06-01 -

Regulating mitochondrial donation seeking expert views - Background document DRAFT.pdf

Human Fertilisation and Embryology Authority (HFEA) (2016a) Freezing and Storing Eggs. London: HFEA. http://www.hfea.gov.uk/46.html

Human Fertilisation and Embryology Authority (HFEA) (2016b) 'Better Initiatives Around Better Regulation'. Authority Report. $20^{\text {th }}$ January 2016. London: HFEA. pp 1-7. http://www.hfea.gov.uk/docs/2016-01-20 Authority Papers _ Final.pdf Human Fertilisation and Embryology Authority (HFEA) (2016c) Fertility Treatment: Trends and Figures 2014. London: HFEA. 
Human Fertilisation and Embryology Authority (HFEA) (2016d) Annual Report and Accounts 2015-16. London: HFEA.

https://www.gov.uk/government/uploads/system/uploads/attachment data/file/542689/HF EA Annual report 2015-16 WEB.pdf

Human Fertilisation and Embryology Authority (HFEA) (2016e) Innovation and Regulation Plan 2016/17. HFEA: London.

http://www.hfea.gov.uk/docs/HFEA innovation plan draft.pdf

Human Reproductive Cloning Act (2001) UK Act of Parliament. London: HMG.

http://www.legislation.gov.uk/ukpga/2001/23/pdfs/ukpga 20010023 en.pdf

Hunt, Lord Hunt of Heath (2015). Deregulation Bill: Exercise of regulatory functions: economic growth. $11^{\text {th }}$ February 2015. House of Lords, Hansard Text: Column 1237.

http://www.publications.parliament.uk/pa/ld201415/ldhansrd/text/150211$\underline{0001 . h t m \# 15021191001285}$

Huntingdon, Samuel, P. (1953) The Marasmus of ICC: The Commission, the Railroads and the Public Interest. Yale Law Journal. Vol 61. pp 467-509.

Institute for Government (2010) Read Before Burning: Arms' length government for a new administration. London: IfG.

Johnson, Simon., and Kwark, James. (2010) 13 Bankers: The Wall Street Takeover and the New Financial Meltdow. New York: Panthleon. pp 104-5.

Judd, Lord Judd (2010) Public Bodies Bill. $9^{\text {th }}$ November 2010. House of Lords, Hansard Text: Column 141. http://www.publications.parliament.uk/pa/ld201011/ldhansrd/text/101109$\underline{0001 . h t m \# 10110950000414}$

Kaldor, Nicholas. 1939. "Welfare Propositions in Economics and Interpersonal Comparisons of Utility.” Economic Journal 49(145): 549-52.

King, Sir Mervyn, Governor of the Bank of England (2011). Addressing the Draft Financial Services Bill. $18^{\text {th }}$ October 2011.

www.telegraph.co.uk/finance/newsbysector/banksandfinance/8868041/Bank-of-Englandshould-be-left-alone-to-police-banks-says-Governor-Sir-Mervyn-King.html

Kwak, James. (2014) 'Cultural Capture and the Financial Crisis' in David Carpenter and David, A. Moss (Eds) (2014) Preventing Regulatory Capture: special interest influence and how to limit it. Cambridge: Cambridge University Press. pp 71-98. 
Laidlaw, James. (2003) 'A Free Gift Makes No Friends'. Journal of the Royal Anthropological Institute. Vol 6. Issue 4. pp 617-634.

Levi-Faur, David. (2011) 'Regulation and Regulatory Governance' in David, Levi-Faur (Ed) Handbook on the Politics of Regulation. Massachusetts: Edward Elgar Publishing. pp 3-24.

Levine, Michael. E., and Forrence, Jennifer, L,. (1990) Regulatory Capture, Public Interest, and the Public Agenda: Towards a Synthesis. Journal of Law, Economics \& Organization. Vol 6. pp 167-198.

Lindblom, Charles (1977), Politics and Markets (New York: Basic Books).

Lindsay, $16^{\text {th }}$ Earl of Lindsay (2015) Exercise of regulatory functions: economic growth. $4^{\text {th }}$ March 2015, House of Lords, Hansard Text: Column 294.

http://www.publications.parliament.uk/pa/ld201415/ldhansrd/text/150304-0002.htm

Maude, Francis (2010) Public Body Review Published. 14 October 2010. HMG: London.

https://www.gov.uk/government/news/public-body-review-published

Maude, Francis (2011a) 'Quango reforms take a leap forward as Public Bodies Act receives Royal Assent'. Cabinet Office Press Release. 15 December 2011. HMG: London.

https://www.gov.uk/government/news/quango-reforms-take-a-leap-forward-as-public-bodiesact-receives-royal-assent

Maude, Francis (2011b) Written Ministerial Statement Public Bodies Act 2011. Cabinet Office. 15

December 2011. HGM: London.

https://www.gov.uk/government/uploads/system/uploads/attachment data/file/62124/Writt en Ministerial Statement Public Bodies Act 2011.pdf

Mauss, Marcel, 1990 [1954]. The Gift: The Form and Reason for Exchange in Archaic Societies.

Routledge: London.

McCarty, Nolan. (2014) Complexity, Capacity and Capture in David Capenter and David, A.

Moss (Eds) (2014) Preventing Regulatory Capture: special interest influence and how to limit it. Cambridge:

Cambridge University Press. pp 99-123.

McCracken, Justin. (2013) Review of the Human Fertilisation \& Embryology Authority and the Human Tissue Authority. An Independent Report to the Parliamentary Under Secretary of State for Public Health and the Minister for the Cabinet Office by Justin McCracken. HMG: London. 
https://www.gov.uk/government/uploads/system/uploads/attachment data/file/216947/Justi $\underline{n}$ McCracken report of review of HFEA and HTA.pdf

Midland Fertility Clinic (2012) The MFS 25 th Anniversary 25 Milestone Babies. Tamworth. MFS. http://www.midlandfertility.com/2012/07/newsletter-issue-25-made-in-aldridge/

Mitnick, Barry, M. (2011) 'Capturing “capture”: definition and mechanisms' in David, Levi-Faur (Ed) Handbook on the Politics of Regulation. Edward Elgar Publishing. pp 34-49.

Needham, Carol, A. (2010) Listening to Cassandra: 'The Difficulty of Recognizing Risks and Taking Action'. Fordham Law Review (78), pp2347-2355.

O’Neill, Onora. (2002) Autonomy and Trust in Bioethics. Cambridge: Cambridge University Press.

Peebles, Gustav. (2010). The anthropology of credit and debt. Annual Review of Anthropology (39), p225-240.

Peltzman, Sam. (1976) "Toward a More General Theory of Regulation," Journal of Law and Economics, vol. 19. pp. 211-40.

Peltzman, Sam. (1989). The economic theory of regulation after a decade of deregulation. Washington: Brookings Papers Microeconomics.

Pigou, Arthur. C. (1932) The Economics of Welfare. London: Macmillan and Co.

Posner, Richard. (1980). "The Ethical and Political Basis of the Efficiency Norm in Common Law Adjudication.” Hofstra Law Review 8:487-507.

Public Bodies Act (2011). UK Act of Parliament. London: HMG. http://www.legislation.gov.uk/ukpga/2011/24/pdfs/ukpga 20110024 en.pdf

Rhan, Richard, W. (2011) Regulators Causing Bank Failures. Washington DC: Cato Institute Rutter, Jill. (2014) The Quango Conundrum Revisited—Why the Government Still Needs a More Coherent Approach to Arm's-Length Bodies. The Political Quarterly, Vol. 85, No. 2. pp 148152.

Schieffelin, Edward. (1980), 'Reciprocity and the Construction of Reality', Man, 15 (3). pp 502 517.

Schwarcz, Daniel. (2014) 'Preventing Capture Through Consumer Empowerment Programs: Some evidence form insurance regulation' in Daniel Carpenter and David, A. Moss (Eds), 
Preventing Regulatory Capture: Special Interest Influence and How to Limit it. Cambridge. University of Cambridge Press. pp 365-396.

Shamoun, Dima Yazji, and Yandle, Bruce (2016) Asserting presidential preferences in a regulatory review bureaucracy. Public Choice. Vol.166 Issue 1. pp87-111

Stigler, George, J. (1975) The Citizen and the State: Essays on Regulation. Chicago. University of Chicago Press.

Strathern, Marilyn. (1992) The Gender of the Gift: Problems with Women and Problems with Society. Berkeley. University of California Press.

Sorauf, Frank, J. (1957) The Public Interest Reconsidered. The Journal of Politics. Vol.19 No. 4. pp 616-639.

Sunstein, Cass, R. (2014) Simpler: The Future of Government. New York: Simon \& Schuster.

Sunstein, Cass R., Output Transparency vs. Input Transparency (May 25, 2017). Available at SSRN: https://ssrn.com/abstract=2826009 or http://dx.doi.org/10.2139/ssrn.2826009

Thornton, Baroness Thornton (2010) Public Bodies Bill. $9^{\text {th }}$ November 2010. House of Lords, Hansard Text: Column 155.

http://www.publications.parliament.uk/pa/ld201011/ldhansrd/text/101109_$\underline{0001 . h t m \# 10110950000414}$

Trump, Donald (2016) First 100 Days Plan. CNN News. USA. http://edition.cnn.com/2016/11/21/politics/donald-trump-outlines-policy-plan-for-first-100days/

Verhoest, Koen., van Thiel, Sandra., Bouckaert, Geert and Lægreid, Per. (2012). Government Agencies: Practices and Lessons from 30 Countries. London: Palgrave.

Wagner, Wendy (2010) Administrative Law, Filter Failure, and Information Capture, Duke Law Journal Vol.59. pp 1321-1432.

'Warnock Report' (1984) Department of Health and Social Security: Report of the Committee of Inquiry into Human Fertilisation and Embryology. London: Her Majesty's Stationary Office. http://www.hfea.gov.uk/docs/Warnock Report of the Committee of Inquiry into Human Fertilisation and Embryology 1984.pdf 
Warren, Mark. E. (1999) 'Conclusion' in Mark. E Warren (Ed) Democracy and Trust. Cambridge: Cambridge University Press.

Welfare for Women Bill (2016). House of Lords, UK Parliament. London: HMG.

http://services.parliament.uk/bills/2015-

$\underline{16 / \text { welfareofwomenfertilitytreatments/documents.html }}$

Winston, Lord Winston (2015). Deregulation Bill: Exercise of regulatory functions: economic growth. $11^{\text {th }}$

February 2015. House of Lords, Hansard Text: Column 1238.

http://www.publications.parliament.uk/pa/ld201415/ldhansrd/text/150211-

$\underline{0001 . h t m \# 15021191001285}$

Yandle, Bruce (1983) "Bootleggers and Baptists: The Education of a Regulatory

Economist," Regulation, May/June. 1983: 12-16.

Zingales, Luigi (2014) Preventing Economists' Capture in David Capenter and David, A. Moss

(Eds) (2014) Preventing Regulatory Capture: special interest influence and how to limit it. Cambridge:

Cambridge University Press. pp 124-151.

Zupan, Mark (2017) Inside Job: How Government Insiders Subvert the Public Interest.

Cambridge: Cambridge University Press. 